\title{
ASSESSING THE EFFECTS OF SUBSTITUTION AND SUBSTITUENT POSITION ON THE REACTIVITY OF SALICYLIDENEANILINE LIGANDS TO COORDINATE TRANSITION METAL(II) IONS: A DFT STUDY
}

\author{
Sellami Mohamed ${ }^{1}$, Barkat Djamel1, Hachani Salah Eddine ${ }^{2, 凶}$
}

https://doi.org/10.23939/chcht15.03.343

\begin{abstract}
The present scientific contribution aims to investigate computationally the effects of substitution and substituent position on the reactivity of a series of salicylideneaniline derivatives ligands containing 13 molecules. Global reactivity parameters such as the $E_{\mathrm{HOMO}}$, $E_{\mathrm{LUMO}}$, gap energy, electronegativity, chemical hardness, chemical softness, electrophilicity index, and molecular electrostatic potential analysis (MESP) have been calculated at DFT/B3LYP/TZP level of theory and then well discussed to give valuable explanations for the effects of substitution and substituent position on the reactivity of the studied ligands.
\end{abstract}

Keywords: reactivity, salicylideneaniline, ligands, DFT.

\section{Introduction}

Transition metals complexes are versatile chemical compounds widely used for their excellent electroluminescence and fluorescence properties in industrial purposes such as homogeneous and heterogeneous catalysis, sensors, photovoltaic materials, and organic light emitting diode (OLED) display technology [1, 2]. These organometallic compounds also exhibit a broad range of biological activities and hold promise to be used as antifungal, antibacterial, antimalarial, and antiinflammatory drugs [3].

Schiff bases are organic compounds containing azomethine functional group $(-\mathrm{HC}=\mathrm{N}-)$. This type of molecules is obtained by condensation of ketones or aldehydes with primary amines [4]. Schiff bases have gained big popularity in the field of materials science due to their potential advantages such as easy synthetic route, high purity, low toxicity, and their eco-friendly nature [5].

\footnotetext{
${ }^{1}$ Laboratory of Molecular Chemistry and Environment, University of Biskra, BP 145, 07000 Biskra, Algeria

${ }^{2}$ Applied Chemistry Laboratory, University of Biskra, BP 145, 07000 Biskra, Algeria

salaho_hachani@yahoo.fr

(c) Mohamed S., Djamel B., Eddine H., 2021
}

Experimental studies have reported a significant biological activity in antibiotic, antifungal, antiviral, antiapoptotic, and anti-inflammatory agents for the abovementioned compounds [6].

The use of Schiff bases as ligands in coordination chemistry has received considerable attention due to the high capability of such compounds to coordinate metal atoms and form stable metal complexes. The resulting complexes are extensively used in many fields, such as biology, medicine, optics, and electronic devices [7].

Different laboratory techniques are not enough convincing to explain the reactivity of ligands towards metal ions. Computer software and hardware advances open the door to the scientists to use theoretical chemistry as a powerful tool to understand the capacity of ligands for coordinating metals. Density functional theory (DFT) methods are reliable theoretical approaches largely used in coordination chemistry to elucidate the reactivity of ligands as well as to predict different structural and spectroscopic features of metal complexes [8].

Theoretical studies in gas and aqueous phase showed that the ligand reactivity to coordinate metal atoms is strongly related to quantum chemical descriptors such as the energy of the highest occupied molecular orbital $\left(E_{\text {Номо }}\right)$ and the energy of the lowest unoccupied molecular orbital $\left(E_{\text {LUMO }}\right)$, electronegativity $(\chi)$, hardness $(\eta)$, softness $(\sigma)$, gap energy $(\Delta E)$, chemical potential $(\mu)$, and electrophilicity index $(\omega)$ [9].

Salicylideneaniline and its derivatives (Fig. 1) have attracted a great attention in the field of organometallic chemistry, new metal complexes based on salicylideneaniline derivatives have been synthesized and their different properties were investigated by several laboratory techniques [10]. Despite the important role of salicylideneaniline derivatives in coordination chemistry, no theoretical background has been proposed yet to study the reactivity and selectivity of these molecules to bind metal ions. 


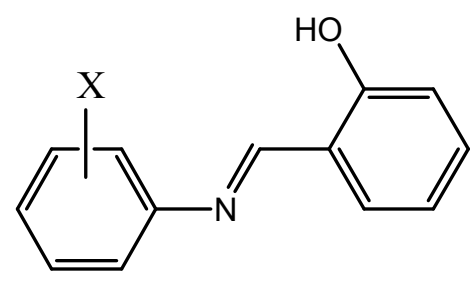

Fig. 1. Chemical structure of salicylideneaniline

The present paper aims to investigate the molecular and electronic properties of a series of salicylideneaniline ligands. Global reactivity descriptors such as $E_{\mathrm{HOMO}}$,

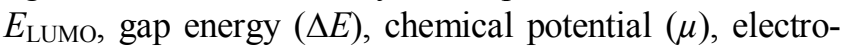
negativity $(\chi)$, chemical hardness $(\eta)$, chemical softness $(\sigma)$, and electrophilicity index $(\omega)$ are calculated and then discussed to elucidate the impact of substitution and substituent position on the reactivity of the molecules under investigation to coordinate transition metal(II) ions.

\section{Computational Details}

Geometry optimization of the studied salicylideneaniline derivatives was performed using density functional theory (DFT) calculations. Beck's three-parameter exchange functional along with the LeeYang-Parr non-local correlation hybrid functional (B3LYP) combined with triple zeta polarization (TZP) basis set were used in the present work. The integration parameter was set to be 6 [11]. All the computations have been performed at the deprotonated form of the molecules under study using Amsterdam Density Functional (ADF) program package [12]. Let us consider the atom numbering as shown in Fig. 2.

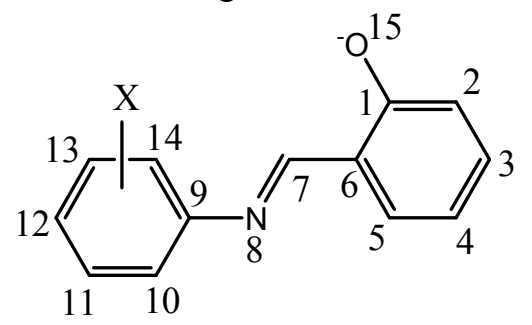

Fig. 2. Atom numbering of the examined ligands

The quantum chemical results were used to calculate quantum descriptors to estimate the reactivity of the molecules under probe. According to Koopmans' theory, ionization potential (I) and electronic affinity $(A)$ are directly related to frontier molecular orbital energies, these electronic parameters can be calculated as follows [13]:

$$
\begin{gathered}
I=-E_{\text {HОMO }} \\
A=-E_{\text {LUMO }}
\end{gathered}
$$

According to Pearson's theory, quantum descriptors such as electronegativity $(\chi)$, global hardness $(\eta)$ and global softness $(\sigma)$ are expressed as follows [14]:

$$
\begin{gathered}
\chi=\frac{I+A}{2} \\
\eta=\frac{I-A}{2} \\
\sigma=\frac{2}{I-A}
\end{gathered}
$$

The electrophilicity index $(\omega)$ represents the power of a molecule to accept electron; this quantum parameter is calculated using the following equation [15]:

$$
\omega=\frac{\mu}{2 \eta}^{2}=\frac{\chi^{2}}{2 \eta}
$$

where $\mu$ represents the chemical potential of the selected chemical species.

\section{Results and Discussions}

In solution, salicylideneaniline derivatives can be easily deprotonated according to the reaction presented in Fig. 3.

In such case, the deprotonated salicylideneaniline derivatives act as bidentate ligands in the coordination process with transition metal(II) ions; this is attributed to the presence of lone pair of electrons of azomethine nitrogen atom as well as the deprotonated phenol oxygen in their molecular structures. The above coordination process is described in Fig. 4.

Recently, there has been growing interest in using theoretical calculations to predict the chemical behavior of the above mentioned ligands. The current computational contribution treats the effects of substitution and substituent position on the reactivity and selectivity of salicylideneaniline ligands containing halogen and methyl substituents in different ortho-, meta- and para-positions using DFT calculations. The fully optimized geometries of the ligand molecules under probe at DFT/B3LYP/TZP level of theory are shown in Fig. 5. The computed global reactivity descriptors associated to the selected chemical species are collected in Table 1.

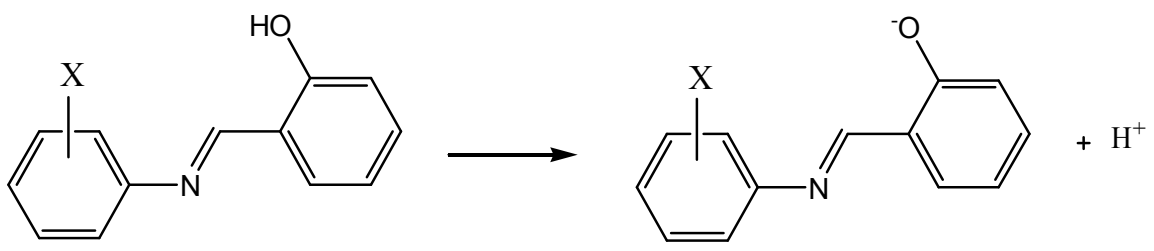

Fig. 3. Deprotonation process of salicylideneaniline derivatives 
Fig.4. Proposed coordination scheme of deprotonated salicylideneaniline ligand with transition metal(II) ions<smiles>[X]c1cccc(/N=C/c2ccccc2[O-])c1</smiles><smiles>[X]c1ccccc1/N=C/c1ccccc1ON(C)/C=N/c1ccccc1Oc1ccccc1</smiles>

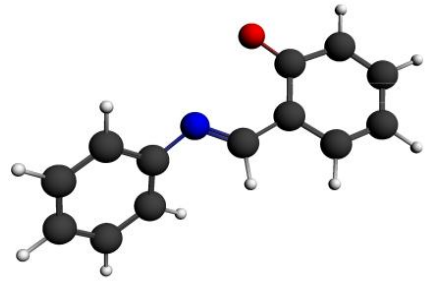

L

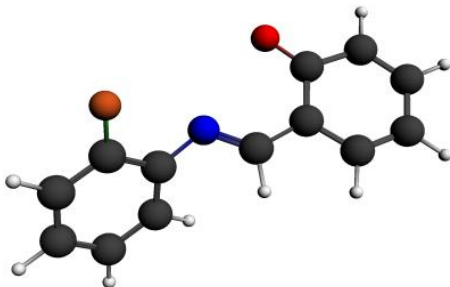

LF1

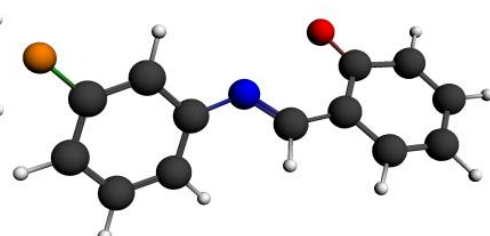

LF2

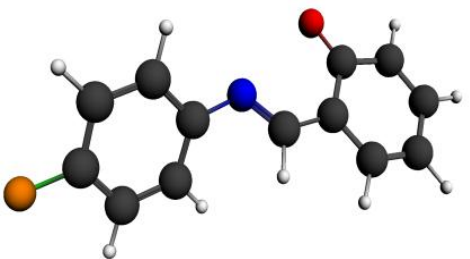

LF3

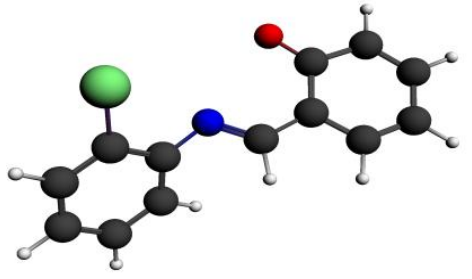

LCI1

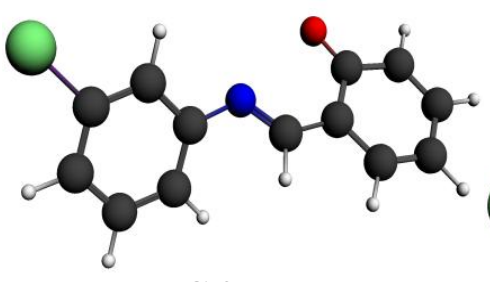

LCl2

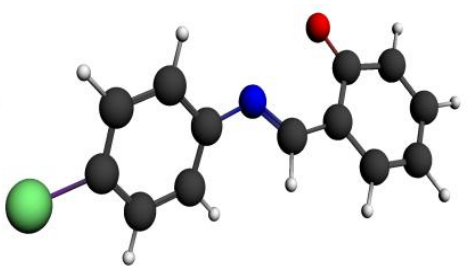

LCI3

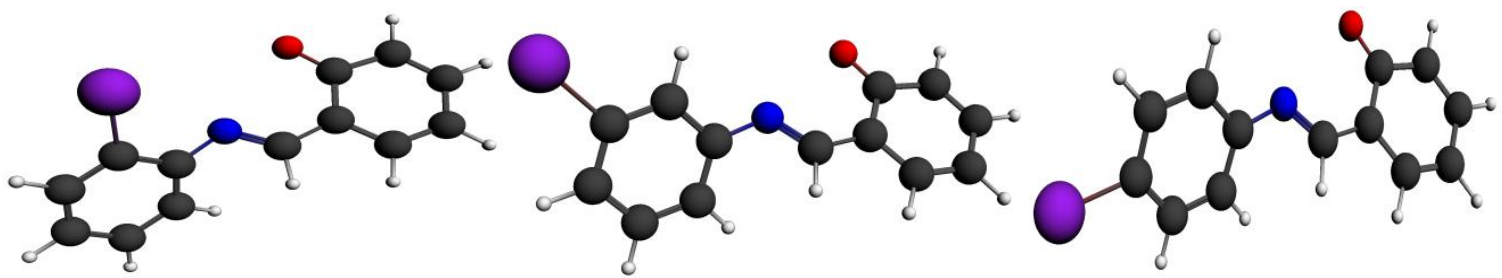

LBr1

LBr2

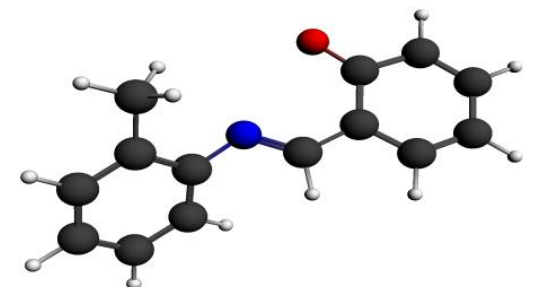

LM1

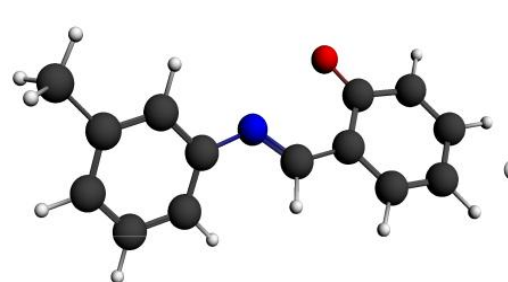

LM2

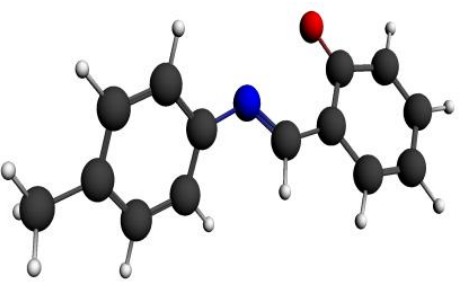

LM3

Fig. 5. Optimized molecular structures of the salicylideneaniline ligands at B3LYP/TZP level of calculation 
Global reactivity descriptors of the tested chemical species computed at B3LYP/TZP level of theory (in $\mathrm{eV}$ )

\begin{tabular}{|c|c|c|c|c|c|c|c|c|c|c|}
\hline Position & $\mathrm{Sub}$ & $E_{\text {HOMO }}$ & $E_{\text {LUMO }}$ & $\Delta E$ & $I$ & $A$ & $\chi$ & $\eta$ & $\sigma$ & $\omega$ \\
\hline \multirow{5}{*}{ Ortho } & $\mathrm{H}$ & -1.070 & 2.225 & 3.295 & 1.070 & -2.225 & -0.577 & 1.647 & 0.607 & 0.101 \\
\cline { 2 - 11 } & $\mathrm{F}$ & -1.162 & 2.109 & 3.271 & 1.162 & -2.109 & -0.473 & 1.635 & 0.611 & 0.068 \\
\cline { 2 - 11 } & $\mathrm{Cl}$ & -1.227 & 2.006 & 3.233 & 1.227 & -2.006 & -0.389 & 1.616 & 0.618 & 0.046 \\
\cline { 2 - 10 } & $\mathrm{Br}$ & -1.256 & 1.953 & 3.209 & 1.256 & -1.953 & -0.348 & 1.604 & 0.623 & 0.037 \\
\cline { 2 - 10 } & $\mathrm{CH}_{3}$ & -1.064 & 2.259 & 3.323 & 1.064 & -2.259 & -0.597 & 1.661 & 0.602 & 0.107 \\
\hline \multirow{5}{*}{ Meta } & $\mathrm{H}$ & -1.070 & 2.225 & 3.295 & 1.070 & -2.225 & -0.577 & 1.647 & 0.607 & 0.101 \\
\cline { 2 - 10 } & $\mathrm{F}$ & -1.226 & 2.005 & 3.231 & 1.226 & -2.005 & -0.389 & 1.615 & 0.619 & 0.046 \\
\cline { 2 - 10 } & $\mathrm{Cl}$ & -1.291 & 1.911 & 3.202 & 1.291 & -1.911 & -0.310 & 1.601 & 0.624 & 0.030 \\
\cline { 2 - 10 } & $\mathrm{Br}$ & -1.315 & 1.871 & 3.186 & 1.315 & -1.871 & -0.278 & 1.593 & 0.627 & 0.024 \\
\cline { 2 - 10 } & $\mathrm{CH}_{3}$ & -1.050 & 2.227 & 3.277 & 1.050 & -2.227 & -0.588 & 1.638 & 0.610 & 0.105 \\
\hline \multirow{5}{*}{ Para } & $\mathrm{H}$ & -1.070 & 2.225 & 3.295 & 1.070 & -2.225 & -0.577 & 1.647 & 0.607 & 0.101 \\
\cline { 2 - 10 } & $\mathrm{F}$ & -1.156 & 2.150 & 3.306 & 1.226 & -2.150 & -0.497 & 1.653 & 0.604 & 0.074 \\
\cline { 2 - 10 } & $\mathrm{Cl}$ & -1.269 & 1.928 & 3.197 & 1.269 & -1.928 & -0.329 & 1.598 & 0.625 & 0.033 \\
\cline { 2 - 10 } & $\mathrm{Br}$ & -1.296 & 1.878 & 3.174 & 1.296 & -1.878 & -0.291 & 1.587 & 0.630 & 0.026 \\
\cline { 2 - 10 } & $\mathrm{CH}_{3}$ & -1.025 & 2.270 & 3.295 & 1.025 & -2.270 & -0.622 & 1.647 & 0.607 & 0.117 \\
\hline
\end{tabular}

According to ligand field theory (LFT), the complexion process between a ligand and metallic centers can occur due to the donor-acceptor interactions between HOMO orbital of the ligand and $d$ vacant orbitals of the metal atoms [16]. An increase in $E_{\text {HОMO }}$ increases the aptitude of the ligand to give easily electrons to metal atoms [17]. Figs. 6 and 7 exhibit the electronic distributions of HOMO and LUMO frontier orbitals in the studied molecules. The contribution percentage corresponding to the main atoms which participate in the formation of the previously mentioned frontier molecular orbitals are given in Table 2.
Global reactivity descriptors are used to evaluate the properties of a molecule as a whole. Electronegativity $(\chi)$ is an important chemical index that describes the molecule capability to attract electrons [5]. This chemical parameter is very helpful for understanding the ligand reactivity; higher electron donation ability is expected for the ligands having lower electronegativity. It can be seen from the results summarized in Table 1 that the electronegativity values follow the trend: $\mathrm{CH}_{3}<\mathrm{H}<\mathrm{F}<\mathrm{Cl}<\mathrm{Br}$, which means that the chance of the examined ligands to bind metal ions decreased following the sequence: $\mathrm{CH}_{3}>\mathrm{H}>\mathrm{F}>\mathrm{Cl}>\mathrm{Br}$. These results validate the trend in the $E_{\text {Hомо. }}$

Table 2

\section{Contribution rate of different atoms in the formation of HOMO and LUMO frontier orbitals}

\begin{tabular}{|c|c|c|c|c|c|c|c|c|c|c|c|c|}
\hline \multirow{2}{*}{ Position } & \multirow{2}{*}{ Sub } & \multicolumn{5}{|c|}{ Contribution rate in $\mathrm{HOMO}, \%$} & \multicolumn{6}{|c|}{ Contribution rate in LUMO, \% } \\
\hline & & $\mathrm{C}(2)$ & $\mathrm{C}(4)$ & $\mathrm{C}(6)$ & $\mathrm{N}(23)$ & $\mathrm{O}(25)$ & $\mathrm{C}(2)$ & $\mathrm{C}(3)$ & $\mathrm{C}(5)$ & $\mathrm{C}(7)$ & $\mathrm{C}(11)$ & $\mathrm{N}(23)$ \\
\hline \multirow{5}{*}{ Ortho } & $\mathrm{CH}_{3}$ & 13.80 & 20.07 & 19.07 & 08.80 & 22.80 & 06.56 & 09.05 & 09.27 & 20.05 & 11.69 & 07.87 \\
\hline & $\mathrm{H}$ & 13.90 & 21.14 & 19.16 & 08.79 & 22.18 & 06.47 & 08.80 & 09.11 & 19.99 & 12.34 & 07.46 \\
\hline & $\mathrm{F}$ & 14.84 & 21.30 & 19.25 & 08.90 & 23.08 & 06.08 & 08.15 & 08.58 & 19.08 & 08.25 & 06.58 \\
\hline & $\mathrm{Cl}$ & 14.69 & 21.09 & 19.17 & 08.97 & 23.09 & 06.19 & 08.34 & 08.72 & 19.73 & 07.74 & 06.28 \\
\hline & $\mathrm{Br}$ & 13.64 & 20.02 & 17.69 & 09.10 & 23.01 & 06.19 & 08.29 & 08.72 & 20.04 & 07.49 & 06.22 \\
\hline \multirow{5}{*}{ Meta } & $\mathrm{CH}_{3}$ & 13.92 & 21.19 & 19.20 & 08.82 & 23.14 & - & 08.29 & 08.60 & 19.17 & 12.98 & 06.79 \\
\hline & $\mathrm{H}$ & 13.90 & 21.14 & 19.16 & 08.79 & 23.18 & 06. & 08.80 & 09.11 & 19.99 & 12.34 & 07.46 \\
\hline & $\mathrm{F}$ & 13.78 & 21.02 & 19.04 & 08.83 & 22.93 & 06.10 & 08.27 & 08.64 & 19.93 & 13.34 & 06.48 \\
\hline & $\mathrm{Cl}$ & 13.85 & 20.13 & 19.05 & 08.86 & 22.98 & 05.84 & 07.91 & 08.32 & 19.63 & 14.00 & 05.89 \\
\hline & $\mathrm{Br}$ & 13.80 & 20.10 & 19.02 & 08.84 & 22.90 & - & 07.75 & 08.21 & $\begin{array}{l}19.38 \\
\end{array}$ & 08.35 & - \\
\hline \multirow{5}{*}{ Para } & $\mathrm{CH}_{3}$ & 13.92 & 20.15 & 19.17 & 08.70 & 23.64 & - & 08.57 & 08.85 & $\begin{array}{l}19.27 \\
\end{array}$ & 12.17 & 07.32 \\
\hline & $\mathrm{H}$ & 13.90 & 21.14 & 19.16 & 08.79 & 23.18 & 06.47 & 08.80 & 09.11 & $\begin{array}{ll}19.99 \\
\end{array}$ & 12.34 & 07.46 \\
\hline & $\bar{F}$ & 13.85 & 21.10 & 19.11 & 08.77 & 23.11 & 06.65 & 09.05 & 09.34 & 20.41 & 10.62 & 07.94 \\
\hline & $\mathrm{Cl}$ & 13.69 & 21.00 & 19.02 & 08.82 & 22.73 & - & 07.68 & 08.09 & 19.31 & 13.43 & - \\
\hline & $\mathrm{Br}$ & 13.88 & 20.13 & 19.06 & 08.79 & 22.88 & 05.04 & 06.90 & 07.20 & 17.25 & 15.25 & 05.17 \\
\hline
\end{tabular}




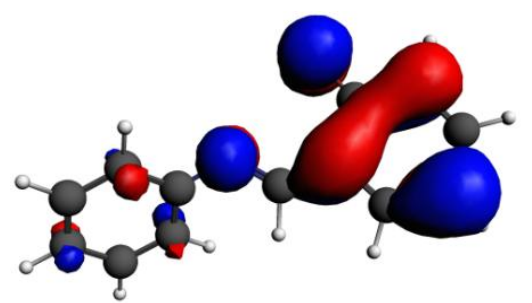

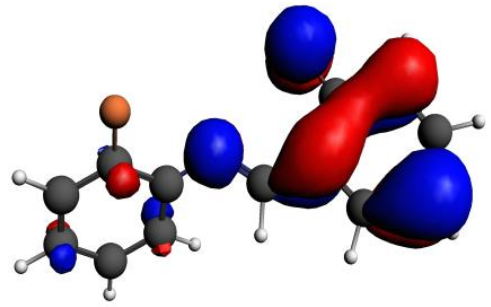

LF1

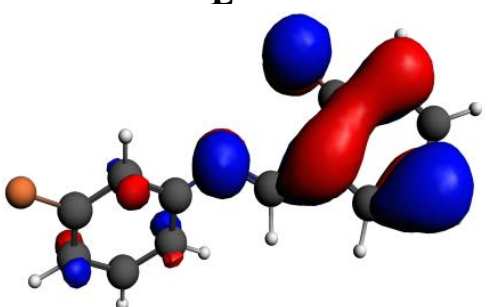

LF2

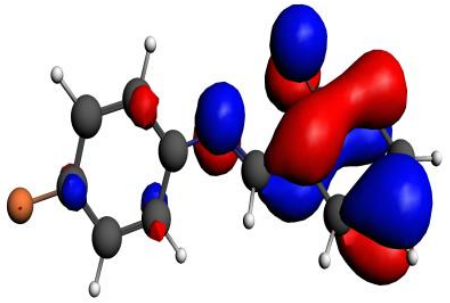

LF3
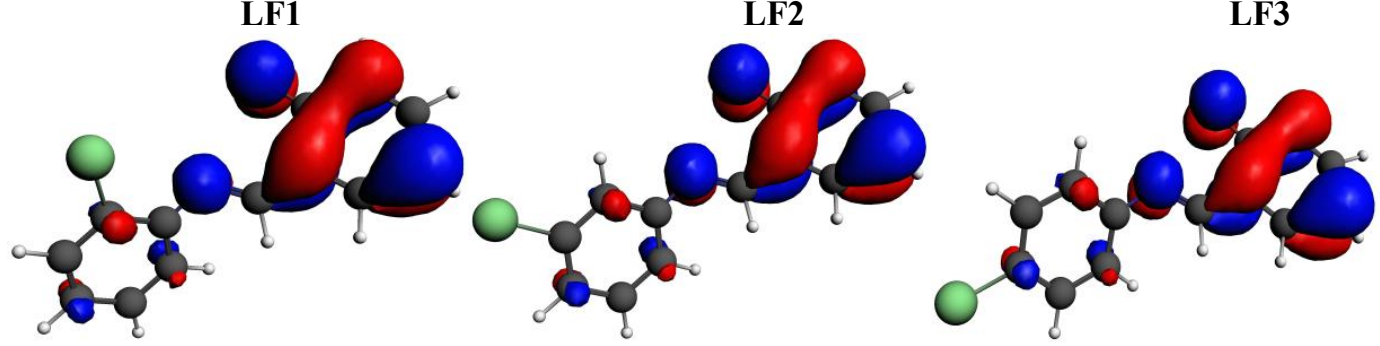

LCl1
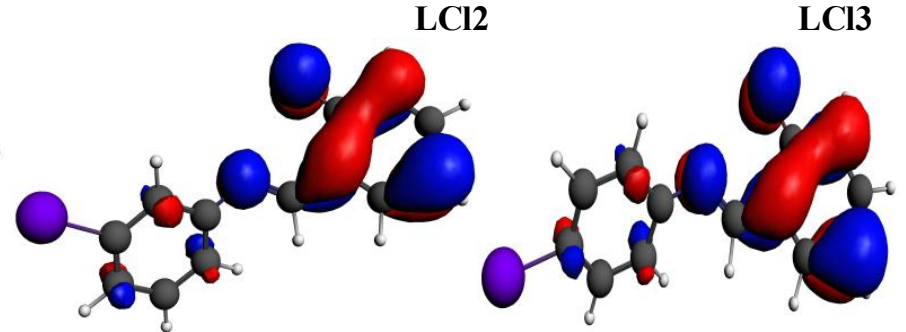

LBr2

LBr3

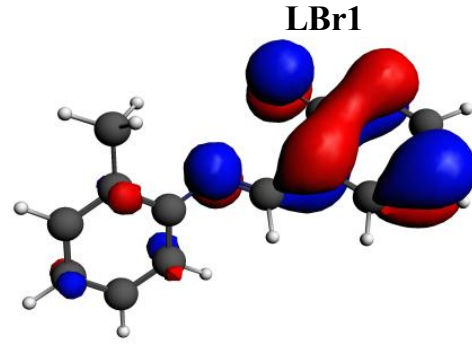

LM1

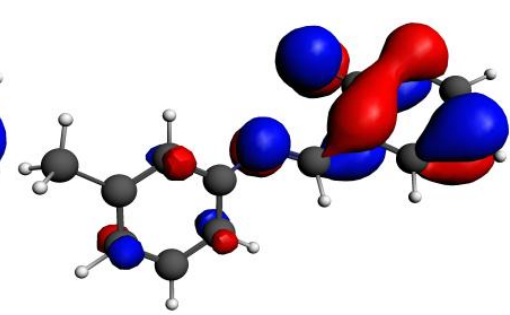

LM2

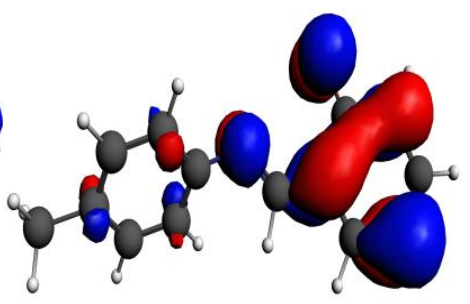

LM3

Fig. 6. HOMO distribution in the studied ligands at B3LYP/TZP level

Global chemical hardness $(\eta)$ fundamentally represents the resistance toward the deformation or polarization of electron cloud of the atoms, ions, or molecules [19]. Chemical hardness is one of extremely important concepts of coordination chemistry. According to hard and soft acid and base (HSAB) principle proposed by Pearson [20], hard acids prefer to coordinate to hard bases and soft acids prefer to coordinate soft bases. The global hardness data displayed in Table 1 shows that the insertion of electron releasing substituents such as methyl group $\mathrm{CH}_{3}$ in ortho position leads to harder Lewis base ligands compared to salicylideneaniline. In contrast, the presence of electron attracting groups such as $\mathrm{F}, \mathrm{Br}$ and $\mathrm{Cl}$ in the same above substitution position decreases Lewis basicity of the studied molecules, leading to softer ligand. However, the presence of the proposed substituents in meta position tends to decrease the chemical hardness, generating softer ligands compared to unsubstituted salicylideneaniline. 


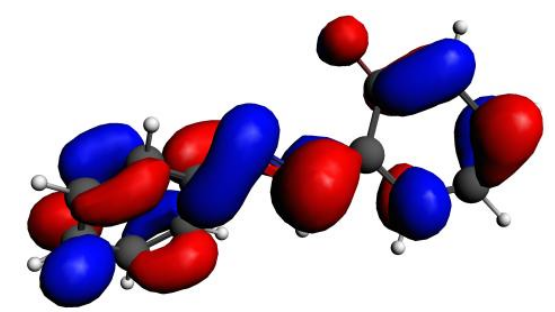

$\mathbf{L}$

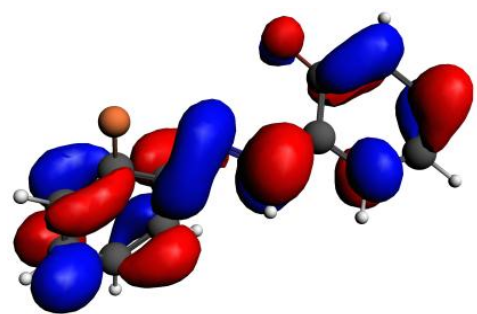

LF1

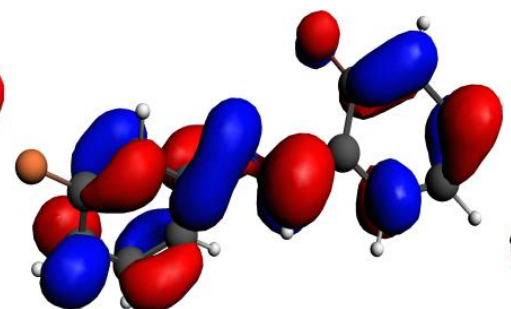

LF2

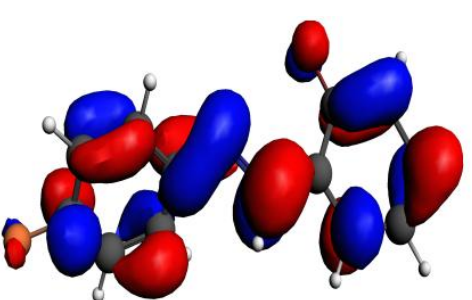

LF3
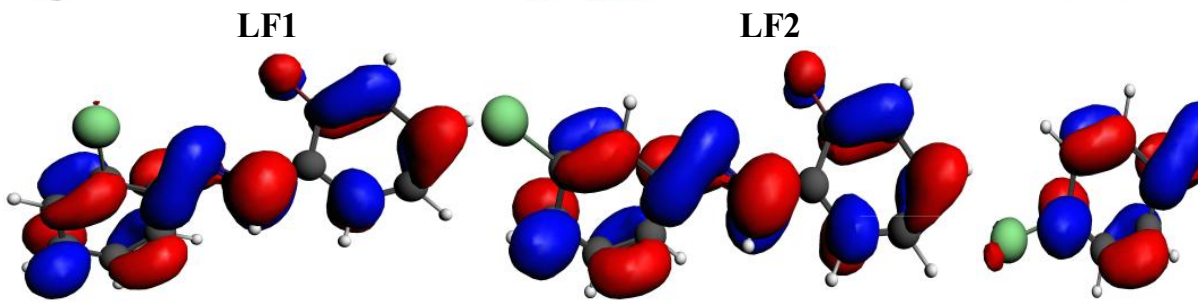

\author{
?
}
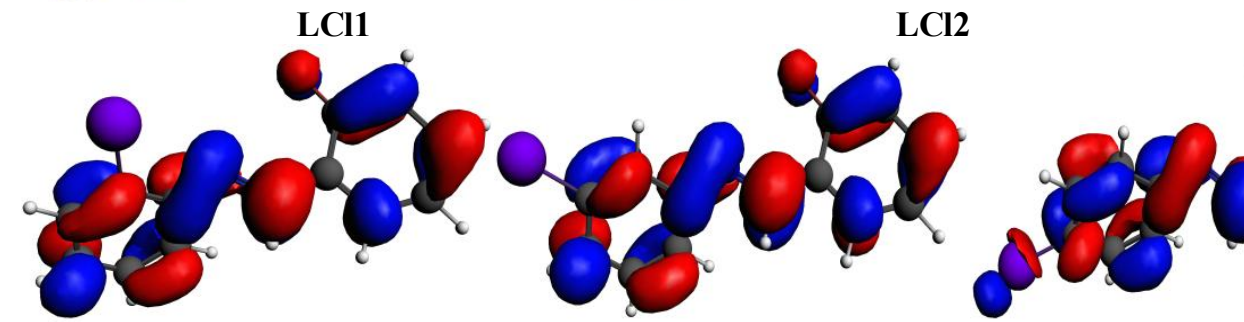

LBr2

\title{
LBr3
}

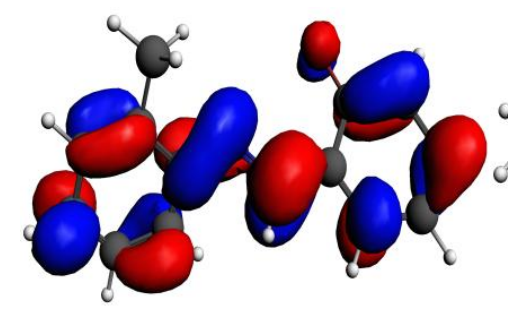

LM1

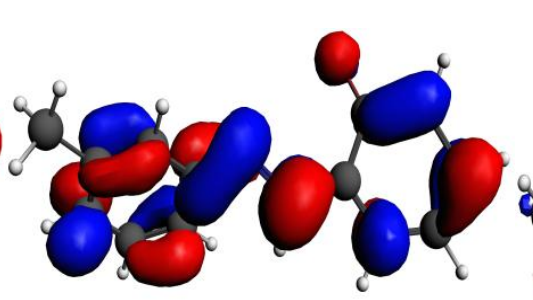

LM2

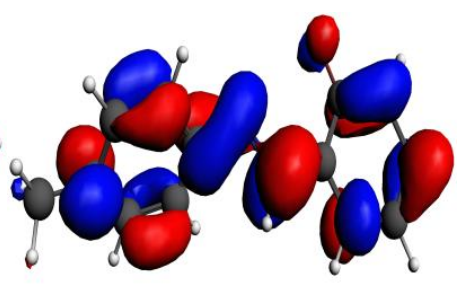

LM3

Fig. 7. LUMO distribution in the studied ligands at B3LYP/TZP level

The concept of electrophilicity index $(\omega)$ as global reactivity descriptor was first given by Parr [21] and represents a measure of the energy stabilization when the chemical system receives an additional charge. This quantum descriptor quantifies the tendency of a molecule for accepting electrons. The electron-donor character of the proposed ligands will be enhanced by low electrophilicity value. Our results in Table 1 show that the $\omega$ values vary following the trend: $\mathrm{CH}_{3}>\mathrm{H}>\mathrm{F}>\mathrm{Cl}>\mathrm{Br}$, indicating that the substitution by halogen atom decreased the electrophilicity index, which implies that the electro- donating power of the studied ligands increased while the substitution by methyl group decreased the ability of ligands to donate electrons to the metal ions centers.

Molecular electrostatic potential (MESP) based electron distribution studies were performed for the first time in 1970 by Tomasi and coworkers [22]; they have calculated the electronic charge distribution of unconjugated molecules as well as small cyclic molecules. MESP analysis is used as a fundamental tool for studying the behavior of atoms and molecules, various noncovalent interactions and molecular properties were well 
interpreted by MESP analysis [23, 24]. Molecular electrostatic potential (MESP) maps help us to visualize the regions of a molecule containing particularly high or low electron density, thus highlighting the reactive centers of the molecule. Regions with the most negative electrostatic potential are shown in red, whereas regions with the most positive electrostatic potential are depicted in blue. As can be seen from MESP maps of the studied chemical species shown in Fig. 8, the most negative electrostatic potential was observed to be localized at $\mathrm{O}$ and $\mathrm{N}$ atoms for all the ligands under investigation, indicating that the these previous atoms can mainly contribute in the coordination process with metal ions. Regarding the electrostatic values corresponding to the studied compounds given in Table 3, it can be seen that the substitution and the substituent position in salicylideneaniline do not apparently affect the ligand behavior towards the metal ions.

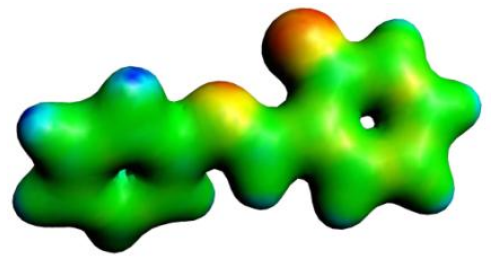

L

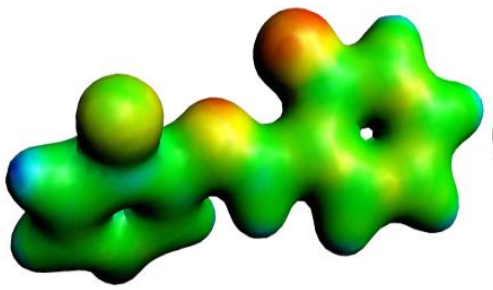

LF1

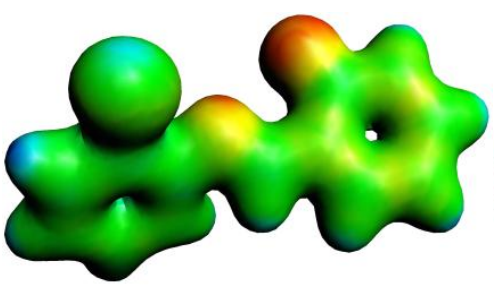

LCl1

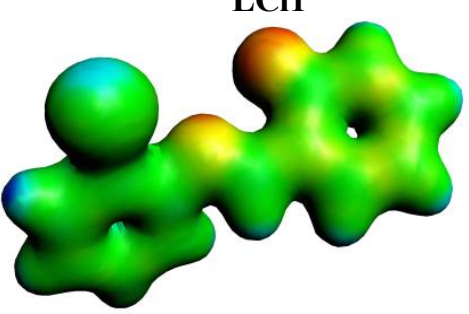

LBr1

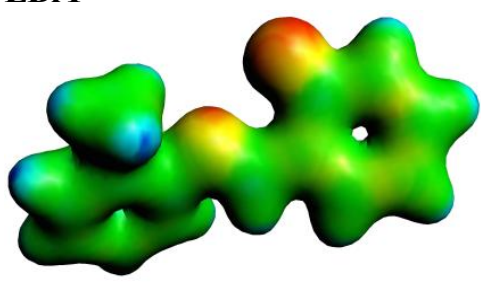

LM1

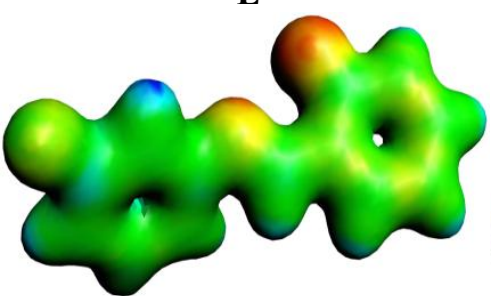

LF2

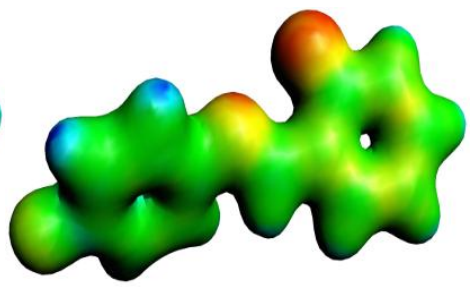

LF3

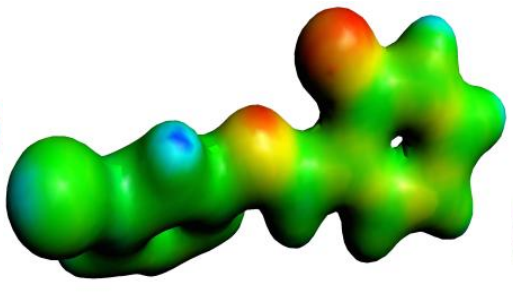

LCl2

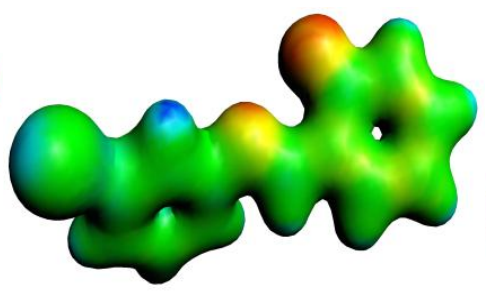

LBr2

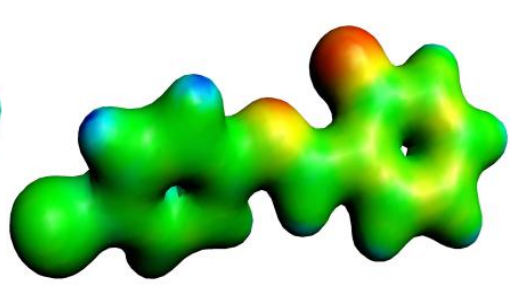

$\mathrm{LCl3}$

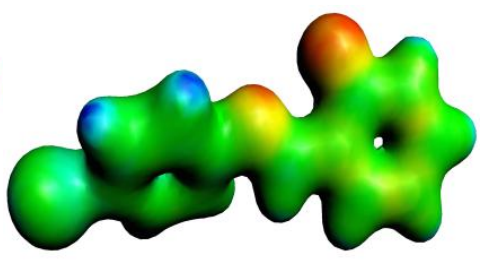

LBr3

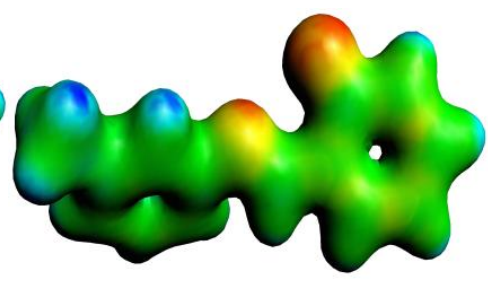

LM2

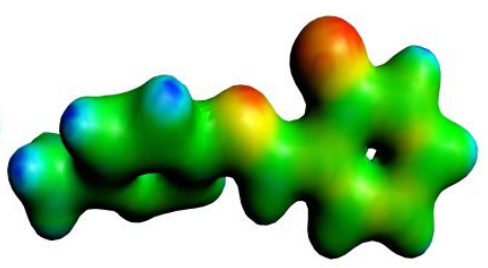

LM3

Fig. 8. MESP maps of the studied chemical species calculated at B3LYP/TZP level 
Table 3

Electrostatic potential values of the studied ligand molecules calculated at B3LYP/TZP level of theory

\begin{tabular}{|c|c|c|c|}
\hline \multirow{2}{*}{ Position } & \multirow{2}{*}{ Sub } & \multicolumn{2}{|c|}{ Electrostatic potential values } \\
\hline & & $\mathrm{O}$ & $\mathrm{N}$ \\
\hline \multirow{5}{*}{ Ortho } & $\mathrm{H}$ & 18.555 & 22.585 \\
\hline & $\mathrm{F}$ & 18.548 & 22.582 \\
\hline & $\mathrm{Cl}$ & 18.547 & 22.579 \\
\hline & $\mathrm{Br}$ & 18.546 & 22.578 \\
\hline & $\mathrm{CH}_{3}$ & 18.555 & 22.585 \\
\hline \multirow{5}{*}{ Meta } & $\mathrm{H}$ & 18.555 & 22.585 \\
\hline & $\mathrm{F}$ & 18.548 & 22.579 \\
\hline & $\mathrm{Cl}$ & 18.545 & 22.577 \\
\hline & $\mathrm{Br}$ & 18.544 & 22.575 \\
\hline & $\mathrm{CH}_{3}$ & 18.556 & 22.586 \\
\hline \multirow{5}{*}{ Para } & $\mathrm{H}$ & 18.555 & 22.585 \\
\hline & $\mathrm{F}$ & 18.551 & 22.582 \\
\hline & $\mathrm{Cl}$ & 18.546 & 22.577 \\
\hline & $\mathrm{Br}$ & 18.545 & 22.576 \\
\hline & $\mathrm{CH}_{3}$ & 18.556 & 22.586 \\
\hline
\end{tabular}

\section{Conclusions}

The global reactivity descriptors of 13 salicylideneaniline derivatives ligands are calculated at DFT/B3LYP/TZP level of theory. These computed descriptors are used to study the reactivity of the salicylideneaniline ligands as $N$-nucleophile towards transition metal ions considered as electrophile. The previous calculations predicted the following:

- Higher $E_{\text {Номо }}$ in the case of electron releasing substituents such as $\mathrm{CH}_{3}$ on salicylideneaniline increases the ligand hardness.

- Global hardness gives an acceptable prediction for the ligand Lewis basicity.

- The substituent position slightly affects the electronic features of the studied salicylideneaniline ligands.

- MESP maps analysis gives beneficial reactive molecular schemes for the studied ligands.

\section{References}

[1] Sorokin A.: Chem. Rev., 2013, 113, 8152.

https://doi.org/10.1021/cr4000072

[2] Priya J., Sharma S.: J. Mater. Sci. Mater. Electron., 2018, 29, 180.

https://doi.org/10.1007/s10854-017-7902-6

[3] Cozzi P.: Chem. Soc. Rev., 2004, 33, 410.

https://doi.org/10.1039/B307853C

[4] Cimerman Z., Miljanic S., Galic N.: Croat. Chem. Acta, 2000, 73, 81.

[5] Hachani S., Necira Z., Mazouzi D., Nebbache N.: Acta Chim. Slov., 2018, 65, 183. https://doi.org/10.17344/acsi.2017.3803

[6] Mukherjee T., Pessoa J., Kumar A., Sarkar A.: Dalton Trans., 2013, 42, 2594. https://doi.org/10.1039/C2DT31575K
[7] Ershad S., Sagathforoush L., Karim-nezhad G., Kangari S.: Int. J. Electrochem. Sci., 2009, 4, 846.

[8] Cramer C., Truhlar D.: Phys. Chem. Chem. Phys., 2009, 11, 10757. https://doi.org/10.1039/b907148b

[9] Soliman S.:Comput. Theor.Chem., 2012, 994, 105.

https://doi.org/10.1016/j.comptc.2012.06.020

[10] Osman A., Aly A., Abd El-Mottaleb, Gouda G.: Bull. Korean

Chem. Soc., 2004, 25, 45. https://doi.org/10.5012/bkcs.2004.25.1.045

[11] Hamprecht F., Cohen A., Tozer D., Handy N.: J. Chem. Phys., 1998, 109, 6264. https://doi.org/10.1063/1.477267

[12] Akbari A., Sheikhshoaie I., Ebrahimipour S.: Arab. J. Chem., 2016, 9, 259. https://doi.org/10.1016/j.arabjc.2011.03.015

[13] Koopmans T.: Physica, 1934, 1, 104. https://doi.org/10.1016/S0031-8914(34)90011-2

[14] Pearson R.: Inorg. Chem., 1988, $27,734$.

https://doi.org/10.1021/ic00277a030

[15] Erdogan S., Safi Z., Kaya S. et al.: J. Mol. Struct., 2017, 1134, 751. https://doi.org/10.1016/j.molstruc.2017.01.037

[16] Griffith J.: Recueil des Travaux Chimiques des Pays-Bas, 1956, 75, 676. https://doi.org/10.1002/recl.19560750613

[17] Ramya K., Anupama K., Shainy K.: Egypt. J. Petrol., 2017, 26,

421. https://doi.org/10.1016/j.ejpe.2016.06.001

[18] Lamsayah M., Khoutoul M., Takfaoui A. et al.: J. Mater. Environ. Sci., 2016, 7, 2796.

[19] Dulal C., Nazmul I.: Int. J. Quantum Chem., 2011, 111, 40. https://doi.org/10.1002/qua.22415

[20] Kaya S., Kariper S., Ungördü A., Kaya C.: Journal of New Results in Science, 2014, 4, 82.

[21] Parr R., Szentpaly L., Liu S.: J. Am. Chem. Soc., 1999, 121, 1922. https://doi.org/10.1021/ja983494x

[22] Scrocco E., Tomasi J.: Top. Curr.Chem., 1973, 42, 95.

[23] Politzer P., Murray J., Lane P.: J. Comput. Chem., 2003, 24, 505. https://doi.org/10.1002/jcc.10209

[24] Ma Y., Politzer P.: J. Chem. Phys., 2004, 120, 8955.

https://doi.org/10.1063/1.1698545 
Assessing the Effects of Substitution and Substituent Position on the Reactivity of Salicylideneaniline...

ОЩІНКА ВПЛИВУ ЗАМІЩЕННЯ

ТА ПОЛОЖЕННЯ ЗАМІСНИКА НА РЕАКЦЙНУ

ЗДАТНІСТЬ САЛІЩИЛІДЕНАНІЛІНОВИХ

ЛІГАНДІВ ДЛЯ КООРДИНУВАННЯ ЙОНІВ

ПЕРЕХІДНИХ МЕТАЛІВ(II):

DFT ДОСЛІДЖЕННЯ

Анотація. Проведені комп'ютерні обчислення впливу заміщення та положення замісника на реакційну здатність ряду лігандів саліциліденніаніліну, що містить 13 молекул. На теоретичному рівні DFT/B3LYP/TZP розраховані глобальні параметри реактивності, такі як $E_{\text {Номо, }} E_{L U м о}$, енергія йонізаиії, електронегативність, хімічна твердість, хімічна м'якість, індекс електрофільності та проведено аналіз молекулярного електростатичного потенціалу. Приведені детальні пояснення впливу заміщення та положення замісника на реакиійну здатність досліджуваних лігандів.

Ключові слова: реактивність, салічиліденанілін, ліган$\partial u, D F T$. 